\title{
Pre-ovulatory arrest and peri-ovulatory redistribution of competent spermatozoa in the isthmus of the pig oviduct
}

\author{
R. H. F. Hunter \\ School of Agriculture, University of Edinburgh, West Mains Road, Edinburgh EH9 3JG, U.K.
}

\begin{abstract}
Summary. Using the surgical approach of post-coital ligation and transection of the distal oviduct at different times relative to ovulation, together with subsequent recovery of the eggs, gilts mated at the onset of oestrus were studied for progression of viable spermatozoa within the isthmus. Results are derived from 76 animals and examination of 1047 eggs.

Transection of the isthmus $1.5-2.0 \mathrm{~cm}$ proximal to the utero-tubal junction at intervals from 3 to $36 \mathrm{~h}$ after mating prevented fertilization in 269 of 270 eggs, whereas $98 \%$ of 223 eggs were fertilized in the control oviducts. Transection at $38 \mathrm{~h}$ (preovulatory), $40 \mathrm{~h}$ (peri-ovulatory) and $42-44 \mathrm{~h}$ (post-ovulatory) after mating yielded, respectively, $5 \%, 40 \%$ and $100 \%$ fertilization. The mean number of spermatozoa associated with the zona pellucida increased in a parallel manner. These results, and those obtained with ligatures placed closer to the site of fertilization just after ovulation, indicate a pre-ovulatory arrest of viable spermatozoa in the caudal region of the isthmus for $36 \mathrm{~h}$ or more followed by an active ad-ovarian redistribution.
\end{abstract}

\section{Introduction}

Transport of spermatozoa from the site of ejaculation to the site of fertilization in the mammalian oviduct has, until quite recently, been regarded as a relatively straightforward progression of motile cells aided by smooth muscle contractions and perhaps also by the action of cilia (reviewed by Dauzier, 1958; Hancock, 1962; Austin, 1964, 1975; Blandau, 1969, 1973; Bedford, 1970a; Thibault, 1973; Hafez \& Thibault, 1975; Mortimer, 1978; Polge, 1978; Harper, 1982). An approximate temporal relationship between semen deposition and ovulation occurs in the large farm animals since females will mate only at a specific phase of the oestrous cycle, but a more precise co-ordination between transport of spermatozoa and shedding of the egg(s) has been demonstrated in sheep. In this species, a population of viable spermatozoa enters the oviducts within 6-8 h of mating early in oestrus (Hunter, Nichol \& Crabtree, 1980; Hunter, Barwise \& King, 1982), whereupon the cells are arrested in the caudal $1-2 \mathrm{~cm}$ of the isthmus for $18 \mathrm{~h}$ or more until shortly before the moment of ovulation (Hunter \& Nichol, 1983). They are then released onwards to the site of fertilization at the ampullary-isthmic junction, apparently showing a much enhanced form of motility, the so-called hyperactivated or whiplash condition (Cummins, 1982). Meeting of the male and female gametes is thought to be regulated, in part at least, by a local endocrine influence of the pre-ovulatory follicle(s) on the oviduct tissues (Hunter, 1982; Hunter, Cook \& Poyser, 1983).

The interval between the onset of oestrus and ovulation of $40-42 \mathrm{~h}$ in domestic pigs is appreciably longer than the corresponding interval of $25-26 \mathrm{~h}$ in sheep, so the pattern of sperm distribution within the oviducts of this polytocous species would be of considerable interest. This is especially so since the base of the oviducts becomes bathed by a dense suspension of spermatozoa during a normal sequence of mating, a situation not found in sheep, cows or goats. Although Hunter 
(1981) reported that a population of spermatozoa sufficient to give maximum fertilization is established in pig oviducts within 1-2 h of mating, the subsequent distribution of viable cells in the oviducts was not examined systematically. Even so, there was tentative evidence from a group of 6 animals that spermatozoa accumulate in and are restricted to the caudal portion of the isthmus for a relatively prolonged period until close to the time of ovulation. The present experiments constitute a detailed study of such storage and release.

\section{Materials and Methods}

\section{Experimental animals}

Large White and Large White $\times$ Landrace gilts, aged $6 \frac{1}{2}-9$ months and weighing $98-140 \mathrm{~kg}$, were housed as groups of 5-8 animals at the Experimental Pig Unit. Oestrous cycles were identified by the twice daily introduction of a mature teaser boar, and animals in mid- to late pro-oestrus were checked for a standing reflex every $2-3 \mathrm{~h}$ between $06: 00$ and $22: 00 \mathrm{~h}$. They were mated at the onset of oestrus by a single Large White boar of proven fertility in the gilt's own pen, after which the boar was returned to a neighbouring pen. Gilts then remained undisturbed until a few minutes before the scheduled start of anaesthesia (Table 1), when they were walked into the adjoining surgical building. A pre-operative period of fasting was not imposed.

\section{Surgical procedures}

Anaesthesia was induced by intravenous injection of pentobarbitone sodium to permit endotracheal intubation, and full surgical anaesthesia was maintained by semi-closed-circuit administration of oxygen, nitrous oxide and halothane. The reproductive tract was exposed through a mid-ventral laparotomy and, with an absolute minimum of manipulation, double ligatures 1-2 mm apart were placed on the oviduct isthmus $1.5-2.0 \mathrm{~cm}$ proximal to the utero-tubal junction. The ligatures of No. 2 gauge Mersilk with atraumatic needle attached (Ethicon Ltd) were carefully passed through the mesosalpinx, avoiding conspicuous blood vessels. The ligatures around one isthmus, placed as a control, were removed with rat-toothed forceps whereas the tissues between the ligatures on the contralateral oviduct were transected with fine-pointed scissors. These procedures of ligation and transection required $\sim 90 \mathrm{sec}$, and were accompanied by strict aseptic precautions.

In a subsidiary group of gilts (Table 2), the distribution of spermatozoa in the oviducts was noted by ligating these structures very soon after ovulation at $3 \cdot 0,3 \cdot 5$ or $4.0 \mathrm{~cm}$ from the uterotubal junction, and then transecting as before.

A third group of animals (Table 3) was used to examine the influence of a second mating by the same boar on sperm distribution in the oviducts. Animals were mated at the onset of oestrus and then again $6,12,24$ or $30 \mathrm{~h}$ later. Ligatures were placed on the isthmus $36 \mathrm{~h}$ after the onset of oestrus (i.e. shortly before ovulation), and the transection made $2.0 \mathrm{~cm}$ proximal to the uterotubal junction.

In all instances, the body wall was closed in three layers with interrupted sutures of braided silk, and animals were placed in individual recovery pens in a warm room $\left(18^{\circ} \mathrm{C}\right)$ next to the operating theatre.

\section{Egg recovery and examination}

Animals were killed at the Edinburgh City abattoir 1-3 days after the operation, and the reproductive tracts were returned to the laboratory within $30-45 \mathrm{~min}$ of slaughter. The ligatures were removed after measuring their location, and the oviducts were dissected free of the mesosalpinx. Each oviduct was flushed towards the uterotubal junction with $40 \mathrm{ml}$ warm Eagle's 
medium (Flow Laboratories) which was collected in new plastic Petri dishes. These were searched under a dissecting microscope and whole mounts of eggs were made by the method of Chang (1952), separate pipettes being used to handle eggs from each oviduct. The fresh preparations were examined under a phase-contrast microscope for spermatozoa attached to or embedded in the zona pellucida, after which eggs were fixed and cleared in $25 \%$ acetic-alcohol (1 part glacial acetic acid : 3 parts ethanol). They were stained with $0.5 \%$ orcein in $45 \%$ acetic acid, the staining solution being drawn very slowly under the coverslip to produce a controlled swelling and dissolution of the zona pellucida. In this manner, a reasonably accurate count could be made of the spermatozoa attached to or embedded in the zona when numbers were $<100$, after which cytoplasmic and nuclear structures were recorded.

\section{Experimental design and analysis}

Transection of the oviduct isthmus was performed at the intervals after mating shown in Tables 1, 2 and 3, all gilts being mated close to the onset of standing oestrus (see above). Gilts first observed in oestrus in the early morning were allocated to the shorter interval transection groups (i.e. 6 or 12 h) to minimize experimental error. Most animals in later groups were mated between 10:00 and 22:00 $\mathrm{h}$ when there was confidence that the gilt would not have stood to the boar $2-3 \mathrm{~h}$ earlier.

Differences between the results of the various treatments were assessed statistically by $\chi^{2}$ analysis for the proportion of eggs fertilized and Student's $t$ test for the mean number of accessory spermatozoa.

\section{Results}

\section{Animals discarded}

Fifteen mated animals are not included in the results for the following reasons: 1 showed the congenital defect of 'blind' uterine horns with the lower portion of each horn absent; 2 were intersexes in which the right gonad was an ovotestis; 1 had large cystic ovaries at autopsy, and 1 was unavoidably killed too late after ovulation and eggs were not recovered from the transected oviduct. (Eggs on the control side were flushed from the uterus.) The 10 remaining animals all yielded unfertilized eggs from the control oviducts, even though mating and the subsequent laparotomy had proceeded without mishap and the female reproductive system appeared morphologically normal.

\section{Animals included}

The results of examination of 1047 eggs recovered from a total of 76 animals are presented in Tables 1,2 and 3.

The major findings (54 animals) are summarized in Table 1, from which it will be noted that transection of the isthmus $1.5-2.0 \mathrm{~cm}$ proximal to the uterotubal junction at intervals extending from 3 to $36 \mathrm{~h}$ after mating prevented, with one exception, subsequent fertilization of eggs in that oviduct. There was therefore no evidence of sperm penetration of the vitellus in 269 of 270 eggs recovered from the transected oviducts of 36 animals, whereas 218 of 223 eggs were fertilized in the control oviducts. Transection at $38 \mathrm{~h}$ after mating yielded 2 fertilized eggs $(5 \cdot 1 \%)$, but thereafter there was a steep and significant increase in the proportion of eggs fertilized. Transection $40 \mathrm{~h}$ after mating at the onset of oestrus, i.e. very close to or during the process of ovulation, resulted in a $40 \%$ incidence of fertilization $(P<0.001)$, whilst transection at $42-44 \mathrm{~h}$ after mating when the ovaries showed recently-collapsed follicles yielded $100 \%$ fertilization in 46 eggs $(P<0.001$; Table 1$)$.

Although the eggs were recovered at different times after ovulation, the numbers of accessory 


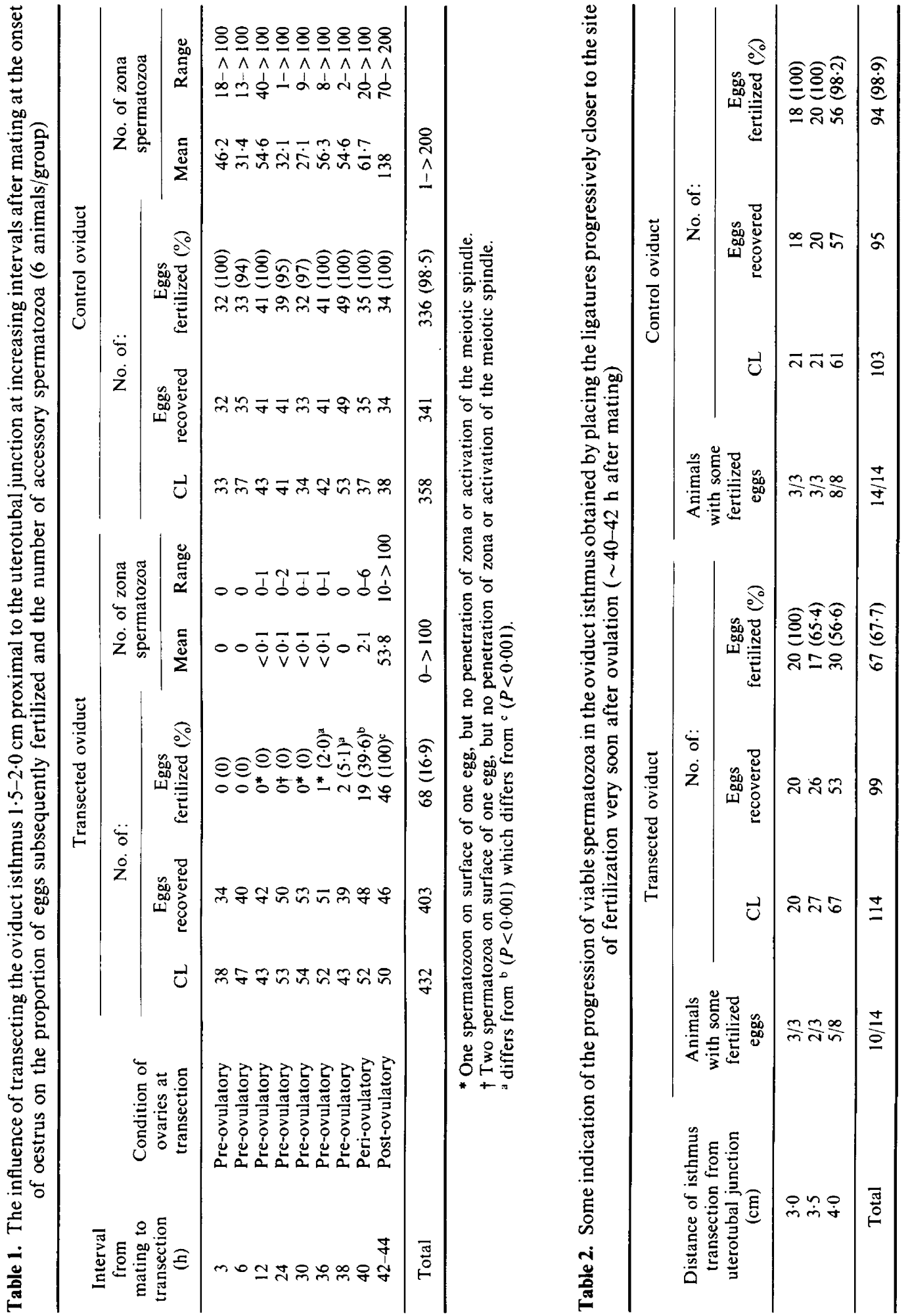


Table 3. The influence of a second mating by the same boar at 4 different intervals after the first mating on the proportion of eggs fertilized in 8 animals in which one oviduct was transected $2.0 \mathrm{~cm}$ proximal to the uterotubal junction $\sim 36 \mathrm{~h}$ after the onset of oestrus

\begin{tabular}{|c|c|c|c|c|c|c|}
\hline \multirow[b]{3}{*}{$\begin{array}{l}\text { Mating } \\
\text { schedule }\end{array}$} & \multicolumn{3}{|c|}{ Transected oviduct } & \multicolumn{3}{|c|}{ Control oviduct } \\
\hline & \multicolumn{3}{|c|}{ No. of: } & \multicolumn{3}{|c|}{ No. of: } \\
\hline & $\mathrm{CL}$ & $\begin{array}{c}\text { Eggs } \\
\text { recovered }\end{array}$ & $\begin{array}{c}\text { Eggs } \\
\text { fertilized }\end{array}$ & $\mathrm{CL}$ & $\begin{array}{l}\text { Eggs } \\
\text { recovered }\end{array}$ & $\begin{array}{c}\text { Eggs } \\
\text { fertilized }\end{array}$ \\
\hline $0^{*}$ and & 6 & 5 & 0 & 9 & 9 & 9 \\
\hline $6 \mathrm{~h}$ later & 10 & 10 & 0 & 6 & 6 & 6 \\
\hline $0^{*}$ and & 8 & 8 & 0 & 7 & 7 & 7 \\
\hline $12 \mathrm{~h}$ later & 4 & 4 & 0 & 9 & 9 & 9 \\
\hline $0^{*}$ and & 3 & 3 & 0 & 8 & 8 & 8 \\
\hline 24 h later & 8 & 7 & 0 & 8 & 6 & 6 \\
\hline $0^{*}$ and & 8 & 7 & 0 & 6 & 6 & 6 \\
\hline $30 \mathrm{~h}$ later & 10 & 9 & 0 & 5 & 5 & 5 \\
\hline Total & 57 & 53 & 0 & 58 & 56 & 56 \\
\hline
\end{tabular}

* Represents mating at the onset of oestrus.

spermatozoa attached to or embedded in the zona pellucida do give some indication of the displacement and/or movement of viable spermatozoa within the oviduct isthmus. Four eggs from the transected oviducts in the 12-36 h 'groups' had 1 or 2 accessory spermatozoa on the surface of the zona (Table 1). Taking these into consideration, the mean numbers of spermatozoa associated with eggs from the control oviducts were still significantly higher $(P<0.01)$ than numbers on the eggs from the transected oviducts up to and including the $38-\mathrm{h}$ group (Table 1). In the 40 -h (periovulatory) group, this difference between eggs from control and transected oviducts was reduced ( $P$ $<0.05$ ), whilst at $42-44 \mathrm{~h}$ the difference was no longer statistically significant.

The results for the 14 animals in which the isthmus was transected closer to the site of fertilization at the ampullary-isthmic junction are summarized in Table 2. Again, there was evidence for a progressive displacement and/or migration of spermatozoa in an ad-ovarian direction close to or just after the time of ovulation. Furthermore, the mean number of spermatozoa associated with the zona pellucida was significantly lower in eggs from the transected compared with the control oviducts $(P<0.05)$, being 22 compared with $>100$ with a $3.0 \mathrm{~cm}$ ligation, 13 and $>100$ with a $3.5 \mathrm{~cm}$ ligation, and 5 and $>100$ with a $4.0 \mathrm{~cm}$ ligation. In the 8 animals with a $4.0 \mathrm{~cm}$ ligation, accessory spermatozoa were absent from 9 of the 30 eggs fertilized in the transected oviducts.

The results from 8 animals subjected to a second mating before transection are presented in Table 3. The procedure of double mating did not alter the incidence of fertilization in the transected oviducts when compared with that reported in Table 1. Spermatozoa were not seen in association with any eggs from the transected oviducts.

\section{Embryonic development}

Development of fertilized eggs presented no obvious aberrations, the great majority of embryos examined $(69 \%)$ being at the $2-4$-celled stage. Consistent differences in the rate of cleavage could not be demonstrated between embryos in the transected oviducts and those in the controls. Polyspermic penetration was detected in a total of 7 pronucleate eggs, all being recovered from the control oviducts. Each of these eggs was dispermic, with apparently delayed or inhibited cleavage. One primary oocyte denuded of all corona cells was also recovered; spermatozoa were not attached to the zona pellucida or within the vitellus (see Polge \& Dziuk, 1965). 


\section{Oviduct dimensions}

In a representative sample of 15 gilts used in this study the lengths of the isthmus and ampulla were measured. On the left side the mean \pm s.d. length of the isthmus was $9.6 \pm 1.2 \mathrm{~cm}$ and the ampulla $18.3 \pm 2.4 \mathrm{~cm}$; on the right side the isthmus was $9.1 \pm 1.4 \mathrm{~cm}$ and the ampulla $18.3 \pm 2.3$ $\mathrm{cm}$. The isthmus therefore comprised $\sim 33 \%$ of the oviduct length, and the $2.0 \mathrm{~cm}$ ligated portion $\sim 20 \%$ of the isthmus, i.e. one fifth of the distance to the site of fertilization.

\section{Discussion}

The results of these studies define, with some precision, the distribution of viable boar spermatozoa within the oviducts of gilts during the relatively long pre-ovulatory interval of $40-42 \mathrm{~h}$. They indicate that a population of spermatozoa capable of fertilizing the eggs accumulates in and is largely restricted to the caudal $2 \mathrm{~cm}$ of the oviduct isthmus until ovulation is imminent. Thus, the population of functional spermatozoa that is established in the oviducts within $1-2 \mathrm{~h}$ of mating at the onset of oestrus (Hunter, 1981) is released and/or displaced rostrally from the lowermost region of the isthmus only in the last hours before collapse of the follicles and shedding of the eggs. This statement is not intended to be absolute in a mathematical sense, for some spermatozoa undoubtedly escape towards the site of fertilization at the ampullary-isthmic junction-as shown by the small number of exceptions in Table 1 . But in the context of attachment to and penetration of the eggs, adequate numbers of competent spermatozoa had not passed beyond the ligatures until $2 \mathrm{~h}$ or so before ovulation. This is emphasized by the fact that only $1.0 \%$ of 309 eggs was fertilized in the ligated oviducts when transection was performed 3-38 h after mating compared with $40 \%$ of 48 eggs with transection $40 \mathrm{~h}$ after mating $(P<0.001)$. Relative to the $40-42 \mathrm{~h}$ interval between the onset of oestrus and ovulation, this indicates a remarkable degree of control over sperm transport within the oviducts and suggests co-ordination in the passage of male and female gametes towards the site of fertilization.

It might be argued that the techniques used in the present studies describe survival of boar spermatozoa in the surgically-modified duct rather than actual distribution within the oviduct lumen. Two lines of evidence indicate that this is not the case. First, the proportion of eggs fertilized in the ligated oviducts increased significantly with peri-ovulatory and then post-ovulatory transection, and the mean number of accessory spermatozoa in the zona pellucida increased in parallel manner, together showing that viability was not the explanation. Second, the results of ligation performed nearer to the site of fertilization underline the progressive redistribution of spermatozoa close to the time of ovulation (Table 2). Moreover, a $70 \%$ incidence of fertilization followed intraperitoneal insemination of small volumes of boar semen shortly before ovulation (Hunter, 1978), so a continuous pre-ovulatory progression of spermatozoa up and out of the control oviduct in the present work might have been expected to lead to some fertilizations in the transected oviduct. Taking these observations together, and also the results of comparable surgical studies in sheep (Hunter \& Nichol, 1983) and cows (Hunter \& Wilmut, 1984), the evidence strongly favours the concept of pre-ovulatory sequestering of viable spermatozoa in the caudal region of the oviduct isthmus. A similar situation occurs in the oviducts of rabbits (Harper, 1973a, b; Overstreet, Cooper \& Katz, 1978; Overstreet \& Cooper, 1979) and the golden hamster (Yanagimachi \& Chang, 1963; Battalia \& Yanagimachi, 1979), although Harper (1973a) suggests that it is the "products of ovulation", the eggs, their investments and/or the follicular fluid, entering the oviducts that leads to movement of spermatozoa towards the site of fertilization.

Accepting that there is a major arrest of boar spermatozoa in the caudal isthmus in the preovulatory interval, the questions arise as to how this control is obtained and why it has evolved. In response to the first question, the lumen of the oviduct isthmus is extremely narrow in oestrous animals, in part due to the oedematous condition of the mucosal folds (Andersen, 1928; Lee, 1928; 
Hunter, 1973), and passage of spermatozoa would be impeded on physical grounds alone. Special consideration must also be given to the myosalpinx. Adrenergic receptors are relatively densely distributed in the circular muscle layer of the isthmus (Rodriguez-Martinez, Garcia, Ohanian \& Einarsson, 1982) and activation of $\alpha$-adrenergic receptors, which promote contraction, is enhanced under oestrogen dominance (Black, 1974; Hunter, 1977), corresponding to the pre-ovulatory situation. In addition to this involvement of the autonomic nervous system, constituents of boar seminal plasma may modify contractile activity of the caudal isthmus. Although seminal plasma was not detected in the oviducts of gilts after mating or artificial insemination by means of biochemical methods (Mann, Polge \& Rowson, 1956), radio-opaque fluid (Polge, 1978) or experiments involving the timing of capacitation (Hunter \& Hall, 1974), subsequent studies using radio-labelled inseminates suggest that very small amounts of seminal plasma do enter the terminal portion of the oviducts soon after mating and may contribute to decreased spontaneous motility of that region (Einarsson, Jones, Larsson \& Viring, 1980) and increased tonus (Einarsson \& Viring, 1973). Quite apart from these considerations of size of the oviduct lumen, the temperature of the isthmus may be lower in the pre-ovulatory period, as has been reported for the rabbit oviduct (David, Vilensky \& Nathan, 1972), a situation that alters abruptly at ovulation or after ovariectomy. Associated with a modified vascular bed, a lower temperature and oxygen tension would together reduce sperm motility (see Overstreet \& Cooper, 1975; Cooper, Overstreet \& Katz, 1979), as might unique fluids in this region of the duct before ovulation (Roblero, Biggers \& Lechene, 1976; Borland, Hazra, Biggers \& Lechene, 1977; Hunter \& Nichol, 1983). In fact, there may well be fundamental parallels between the physiology of temporary sperm storage in the caudal region of the oviduct and the more prolonged phase of storage in the caudal region of the epididymal duct.

Turning to the question of why pre-ovulatory sperm storage in the caudal isthmus has evolved, the most reasonable explanations may concern sperm metabolism and capacitation. Sperm cells have limited metabolic reserves (Mann, 1964) and, in pigs mated at the onset of oestrus, spermatozoa would have to conserve their fertilizing ability for approximately $40 \mathrm{~h}$ until the time of ovulation. Restricting movement of cells in the caudal isthmus and thereby the risk of metabolic exhaustion would seem an appropriate strategy, as would storage of spermatozoa beyond the reaches of the post-coital invasion of polymorphonuclear leucocytes into the uterine lumen (Lovell \& Getty, 1968); there is no evidence for passage of polymorphs into the lumen of the isthmus before ovulation (Fléchon \& Hunter, 1981). As to the final maturation or capacitation of spermatozoa, it would appear essential not to attain this condition until release of the eggs is imminent. Capacitated spermatozoa are unstable, fragile and short-lived cells (Bedford, 1970b; Chang \& Hunter, 1975), in part as a consequence of their hyperactive motility and membranous changes expressed visibly as the acrosome reaction (Yanagimachi, 1981), and there would therefore be no obvious advantage in achieving capacitation many hours before ovulation. The figures of $2-3 \mathrm{~h}$ for capacitation of boar spermatozoa were obtained under post-ovulatory conditions of insemination (Hunter \& Dziuk, 1968), as has been the case for most of the classical studies on capacitation time. Furthermore, there is now circumstantial evidence that the peri-ovulatory events that facilitate redistribution of spermatozoa in the oviduct may themselves promote hyperactivated motility in preparation for penetration of the egg investments (discussed by Hunter \& Nichol, 1983). Coordination of these events, in part at least, is thought to be achieved by a local transfer to the oviduct tissues of high concentrations of ovarian follicular hormones, especially progesterone (Hunter et al., 1983), and an involvement of progesterone in sperm transport and oviduct contractions has been demonstrated directly (Hunter, 1972; Battalia \& Yanagimachi, 1980).

This study was supported by a grant from the Agricultural Research Council. I thank $\mathrm{Mr}$ Robert Nichol for excellent technical assistance; various colleagues in Edinburgh for commenting on a draft of the manuscript; and Mrs Pat Gallie for typing. 


\section{References}

Andersen, D.M. (1928) Comparative anatomy of the tubo-uterine junction. Histology and physiology in the sow. Am. J. Anat. 42, 255-305.

Austin, C.R. (1964) Behaviour of spermatozoa in the female genital tract and in fertilization. Proc. 5th Int. Congr. Anim. Reprod., Trento 3, 7-22.

Austin, C.R. (1975) Sperm fertility, viability and persistence in the female tract. $J$. Reprod. Fert., Suppl. 22, $75-89$.

Battalia, D.E. \& Yanagimachi, R. (1979) Enhanced and co-ordinated movement of the hamster oviduct during the periovulatory period. $J$. Reprod. Fert. 56, 515-520.

Battalia, D.E. \& Yanagimachi, R. (1980) The change in oestrogen and progesterone levels triggers adovarian propulsive movement of the hamster oviduct. $J$. Reprod. Fert. 59, 243-247.

Bedford, J. M. (1970a) The saga of mammalian sperm from ejaculation to syngamy. In Mammalian Reproduction, pp. 124-182. Eds H. Gibian \& E. J. Plotz. Springer-Verlag, New York.

Bedford, J.M. (1970b) Sperm capacitation and fertilisation in mammals. Biol. Reprod. 2, Suppl. 2, 128-158.

Black, D.L. (1974) Neural control of oviduct musculature. In The Oviduct and its Functions, pp. 65-118. Eds A. D. Johnson \& C. W. Foley. Academic Press, New York.

Blandau, R.J. (1969) Gamete transport-comparative aspects. In The Mammalian Oviduct, pp. 129-162. Eds E. S. E. Hafez \& R. J. Blandau. University of Chicago Press.

Blandau, R.J. (1973) Gamete transport in the female mammal. In Handbook of Physiology, Section 7, Endocrinology II, pp. 153-163. Eds R. O. Greep \& E. B. Astwood. American Physiological Society, Washington, D.C.

Borland, R.M., Hazra, S., Biggers, J.D. \& Lechene, C.P. (1977) The elemental composition of the environments of the gametes and preimplantation embryo during the initiation of pregnancy. Biol. Reprod. 16, $147-157$.

Chang, M.C. (1952) Fertilisability of rabbit ova and the effects of temperature in vitro on their subsequent fertilisation and activation in vivo. J. exp. Zool. 121, 351-381.

Chang, M.C. \& Hunter, R.H.F. (1975) Capacitation of mammalian sperm: biological and experimental aspects. In Handbook of Physiology, Section 7, Endocrinology $V$, Ch. 16, pp. 339-351. Eds D. W. Hamilton \& R. O. Greep. American Physiological Society, Washington, D.C.

Cooper, G.W., Overstreet, J.W. \& Katz, D.F. (1979) The motility of rabbit spermatozoa recovered from the female reproductive tract. Gamete Res. 2, 35-42.

Cummins, J.M. (1982) Hyperactivated motility patterns of ram spermatozoa recovered from the oviducts of mated ewes. Gamete Res. 6, 53-63.

Dauzier, L. (1958) Physiologie du déplacement des spermatozoides dans les voies génitales femelles chez la brebis et la vache. Annls Zootech. 7, 281-301.

David, A., Vilensky, A. \& Nathan, H. (1972) Temperature changes in the different parts of the rabbit's oviduct. Int. J. Gynaec. Obstet. 10, 52-56.
Einarsson, S. \& Viring, S. (1973) Effect of boar seminal plasma on the porcine uterus and the isthmus part of the oviducts in vitro. Acta vet. scand. 14, 639-641.

Einarsson, S., Jones, B., Larsson, K. \& Viring, S. (1980) Distribution of small- and medium-sized molecules within the genital tract of artificially inseminated gilts. J. Reprod. Fert. 59, 453-457.

Fléchon, J.E. \& Hunter, R.H.F. (1981) Regulation of sperm transport by the utero-tubal junction and isthmus in pigs: a scanning electron microscope study. Tissue and Cell 13, 127-139.

Hafez, E.S.E. \& Thibault, C.G. (1975) The Biology of Spermatozoa. Transport, Survival and Fertilizing Ability. Karger, Basel.

Hancock, J.L. (1962) Fertilization in farm animals. Anim. Breed. Abstr. 30, 285-310.

Harper, M.J.K. (1973a) Stimulation of sperm movement from the isthmus to the site of fertilisation in the rabbit oviduct. Biol. Reprod. 8, 369-377.

Harper, M.J.K. (1973b) Relationship between sperm transport and penetration of eggs in the rabbit oviduct. Biol. Reprod. 8, 441-450.

Harper, M.J.K. (1982) Sperm and egg transport. In Reproduction in Mammals, 2nd edn, Vol. 1, ch. 5, pp. 102-127. Eds C. R. Austin \& R. V. Short. Cambridge University Press.

Hunter, R.H.F. (1972) Local action of progesterone leading to polyspermic fertilization in pigs. J. Reprod. Fert. 31, 433-444.

Hunter, R.H.F. (1973) Transport, migration and survival of spermatozoa in the female genital tract: species with intra-uterine deposition of semen. In Sperm Transport, Survival and Fertilizing Ability, pp. 309342. Eds E. S. E. Hafez \& C. Thibault. INSERM, Paris.

Hunter, R.H.F. (1977) Function and malfunction of the Fallopian tubes in relation to gametes, embryos and hormones. Eur. J. Obstet. Gynec. Reprod. Biol. 7, 267283.

Hunter, R.H.F. (1978) Intraperitoneal insemination, sperm transport and capacitation in the pig. Anim. Reprod. Sci. 1, 167 179.

Hunter, R.H.F. (1981) Sperm transport and reservoirs in the pig oviduct in relation to the time of ovulation. $J$. Reprod. Fert. 63, 109-117.

Hunter, R.H.F. (1982) Interrelationships between spermatozoa, the female reproductive tract, and the egg investments. In Control of Pig Reproduction, ch. 3, pp. 49-63. Eds D. J. A. Cole \& G. R. Foxcroft. Butterworths, London.

Hunter, R.H.F. \& Dziuk, P.J. (1968) Sperm penetration of pig eggs in relation to the timing of ovulation and insemination. J. Reprod. Fert. 15, 199-208.

Hunter, R.H.F. \& Hall, J.P. (1974) Capacitation of boar spermatozoa: synergism between uterine and tubal environments. J. exp. Zool. 188, 203-214.

Hunter, R.H.F. \& Nichol, R. (1983) Transport of spermatozoa in the sheep oviduct: preovulatory sequestering of cells in the caudal isthmus. J. exp. Zool. 228, 121-128.

Hunter, R.H.F. \& Wilmut, I. (1984) Sperm transport in the cow: peri-ovulatory redistribution of viable cells within the oviduct. Reprod. Nutr. Dévelop. (in press). 
Hunter, R.H.F., Nichol, R. \& Crabtree, S.M. (1980) Transport of spermatozoa in the ewe: timing of the establishment of a functional population in the oviduct. Reprod. Nutr. Dévelop. 20, 1869-1875.

Hunter, R.H.F., Barwise, L. \& King, R. (1982) Sperm transport, storage and release in the sheep oviduct in relation to the time of ovulation. Br. vet. J. 138, 225-232.

Hunter, R.H.F., Cook, B. \& Poyser, N.L. (1983) Regulation of oviduct function in pigs by local transfer of ovarian steroids and prostaglandins: a mechanism to influence sperm transport. Eur. $J$. Obstet. Gynec. Reprod. Biol. 14, 225-232.

Lee, F.C. (1928) The tubo-uterine junction in various animals. Bull. Johns Hopkins Hosp. 42, 335-357.

Lovell, J.E. \& Getty, R. (1968) Fate of semen in the uterus of the sow: histologic study of endometrium during the 27 hours after natural service. Am. J. vet. Res. 29, 609-625.

Mann, T. (1964) The Biochemistry of Semen and of the Male Reproductive Tract. Methuen, London.

Mann, T., Polge, C. \& Rowson, L.E.A. (1956) Participation of seminal plasma during the passage of spermatozoa in the female reproductive tract of the pig and horse. $J$. Endocr. 13, 133-140.

Mortimer, D. (1978) Selectivity of sperm transport in the female genital tract. In Spermatozoa, Antibodies and Infertility, pp. 37-53. Eds J. Cohen \& W. F. Hendry. Blackwells, Oxford.

Overstreet, J.W. \& Cooper, G.W. (1975) Reduced sperm motility in the isthmus of the rabbit oviduct. Nature, Lond. 258, 718-719.
Overstreet, J.W. \& Cooper, G.W. (1979) Effect of ovulation and sperm motility on the migration of rabbit spermatozoa to the site of fertilization. $J$. Reprod. Fert. 55, 53-59.

Overstreet, J.W., Cooper, G.W. \& Katz, D.F. (1978) Sperm transport in the reproductive tract of the female rabbit. II. The sustained phase of transport. Biol. Reprod. 19, 115-132.

Polge, C. (1978) Fertilisation in the pig and horse. $J$. Reprod. Fert. 54, 461-470.

Polge, C. \& Dziuk, P. (1965) Recovery of immature eggs penetrated by spermatozoa following induced ovulation in the pig. J. Reprod. Fert. 9, 357-358.

Roblero, L., Biggers, J.D. \& Lechene, C.P. (1976) Electron probe analysis of the elemental microenvironment of oviducal mouse embryos. J. Reprod. Fert. 46, 431-434.

Rodriguez-Martinez, H., Garcia, R.B., Ohanian, C. \& Einarsson, S. (1982) Histochemical investigation on the distribution of adrenergic nerve terminals in the porcine oviduct. Zbl. VetMed. A 29, 64-71.

Thibault, C. (1973) Sperm transport and storage in vertebrates. J. Reprod. Fert., Suppl. 18, 39-53.

Yanagimachi, R. (1981) Mechanisms of fertilisation in mammals. In Fertilisation and Embryonic Development, Ch. 5, pp. 81-182. Eds L. Mastroianni, Jr \& J. D. Biggers. Plenum Press, New York.

Yanagimachi, R. \& Chang, M.C. (1963) Sperm ascent through the oviduct of the hamster and rabbit in relation to the time of ovulation. J. Reprod. Fert. 6, 413-420.

Received 7 February 1984 